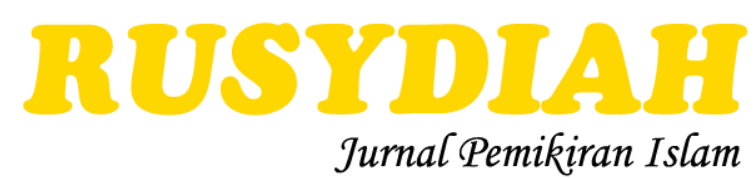

Volume 1 Nomor 2, Desember 2020

ISSN: 2723-4894 (cetak), ISSN: 2723-4886 (daring)

DOI: https://doi.org/10.35961/rsd.v1vi2i.208

\title{
ANALISIS USHLUB AL-MUQOBALAH DI DALAM AL-QUR'AN MELALUI PENDEKATAN BALAGHOH
}

\author{
Aidillah Suja \\ STAIN Sultan Abdurrahman Kepulauan Riau \\ aidillahsuja@stainkepri.ac.id
}

\begin{abstract}
Abstrak
Al-Qur'an dan maknanya berasal dari sisi Allah, ia memiliki ushlub-ushlub yang mengandung mukjizat dan susunan kata yang indah melebihi uslub-uslub Bahasa Arab yang digunakan hari ini. Untuk memahami Al-Qur'an dibutuhkan penguasaan ilmu-ilmu Bahasa Arab khususnya ilmu Balaghah, di antaranya Ushlub Al-Muqobalah. Rumusan masalah dalam penelitian ini adalah apa saja Ushlub Al-Muqobalah yang digunakan di dalam AlQur'an dan apa saja tujuan-tujuan Ushlub Al-Muqobalah di dalam Al-Qur'an. Tujuan penelitian ini adalah untuk mengetahui jenis-jenis Ushlub Al-Muqobalah yang digunakan di dalam Al-Qur'an dan tujuan-tujuannya ditinjau melalui pendekatan Balaghah. Adapun objek penelitian ini adalah ushlub-ushlub Al-Muqobalah yang ada di dalam Al-Qur'an di Juz 30.
\end{abstract}

Kata kunci: Ushlub; Al-Muqobalah; Balaghoh.

\begin{abstract}
The words and the meanings of Al-Qur'an were come from Allah, it has Uslubs miracle that contain and beautiful structure word Arabic uslub that used nowdays. To understand Al-Qur'an need mastery in Arabic grammar especelly Balaghah science, one of them is Ushlub Al-Muqobalah. Formulation problem of this research is what the kinds of Ushlub Al-Muqobalah used in Al-Qur'an and what is his purpose in Al-Qur'an. The purpose of the research is to know the kinds of Ushlub AlMuqobalah used in Al-Quran and to know his purpose, from Balaghoh aspect. This research objects is Uslub Al-Muqobalah in Al-Qur'an at Juz 30.
\end{abstract}

Keywords: Ushlub; Al-Muqobalah; Balaghoh

Rusydiah: Jurnal Pemikiran Islam, Vol. 1, No. 2, Desember, 2020 


\section{PENDAHULUAN}

Al-Qur'an secara bahasa adalah bacaan - sebagaimana contohnya "Saya membaca buku sebagai bacaan atau Qur'anan (bacaan) ${ }^{1}$, dan secara istilah AlQur'an adalah kalamullah SWT sebagai mu'jizat yang diturunkan kepada Rasulullah sebagai wahyu, yang tertulis di dalam mushap-mushap dan terjaga di dalam hati, dibaca dengan lisan, didengar dengan telinga, dan sampai kepada kita melalui jalan mutawatir, dan muta'abbad bi tilawatihi. ${ }^{2}$ Dan dalam buku yang lainnya dikatakan bahwa Al-Qur'an adalah kalamullah SWT yang diturunkan kepada Nabi Muhammad SAW Al-Muta'abbad Bi Tilawatihi. ${ }^{3}$

Sesungguhnya Al-Qur'an telah diyakini oleh para Muslim bahwasannya AlQur'an adalah kalamullah SWT, dan Al-Qur'an merupakan sumber hukum Islam yang pertama. Al-Qur'an merupakan mu'jizat bagi Nabi Muhammad SAW yang dibawakan oleh malaikat Jibril AS. Dan Al-Qur'an ini datang dengan bahasa Arab sebagaimana firman Allah SWT:

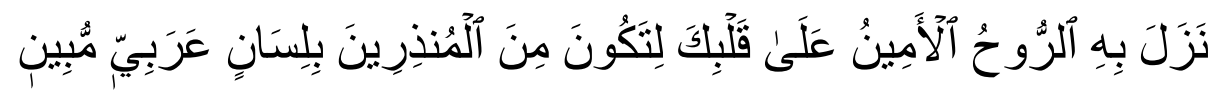

"Dia dibawa turun oleh Ar-Ruh Al-Amin (Jibril). Ke dalam hatimu (Muhammad) agar kamu menjadi salah seorang di antara orang-orang yang memberi peringatan. Dengan bahasa Arab yang jelas". (As-Syu'ara: 193-195).

Telah diketahui bahwa Al-Qur'an datang dengan bahasa Arab dan oleh sebab itu untuk memahami Al-Qur'an dengan baik maka dibutuhkan bahasa Arab juga sebagaimana firman Allah SWT:

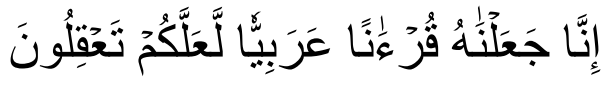

"Sesungguhnya kami menjadikan Al Quran dalam bahasa Arab supaya kamu memahami(nya)". (Az-Zukhruf: 3).

Dan dikarenakan Al-Qur'an merupakan sumber hukum Islam yang pertama maka wajiblah bagi setiap Muslim mengetahui dan memahami bahasa Arab. Dan dalam Bahasa Arab terdapat banyak ilmu yang berkenaan dengannya

1 Taubid 2 Untuk Kelas Lima Kulliyatul Mu'allimin Al-Islamiyyah Di Pondok Modern Darussalam (Ponorogo: Percetakan Darussalam Gontor), p. h. 49.

2 Taubid 2 Untuk Kelas Lima Kulliyatul Mu'allimin Al-Islamiyyah Di Pondok Modern Darussalam, p. h. 49.

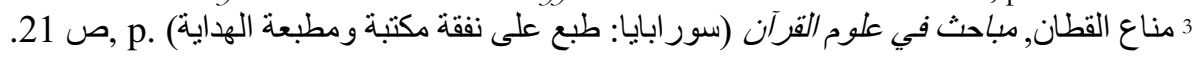


di antaranya adalah nahwu, shorof, balaghah, dan lain sebagainya. Nahwu adalah ilmu yang diketahui dengannya fungsi tiap-tiap kata dalam sebuah kalimat, dan ilmu untuk menentukan baris akhir tiap kata, dan bagaimana i'rabnya. ${ }^{4}$ Shorof adalah ilmu yang membahas tentang perubahan kata dari satu kepada lainnya untuk sampai pada ma'na yang bermacam-macam. ${ }^{5}$

Sungguh telah ditemukan di dalam Al-Qur'an susunan kalimat yang indah dan mempunyai daya tarik dari segi balaghoh. Balaghoh membantu bahasa untuk melaksanakan fungsinya yang mana fungsi itu adalah pengungkapan dan penyampaian, dan Balaghoh merupakan ilmu yang lengkap bagi setiap sisi-sisi kebahasaan baik ma'na maupun lafadz.

Para Ulama Mutaakhirin telah membagi balaghoh kepada tiga bagian yaitu Ilmu Bayan, Ilmu Ma'any, dan Ilmu Badi'. Ilmu Badi' adalah ilmu yang dapat diketahui darinya gambaran keindahan kalam setelah melihat kesesuaian tingkatan kondisi manusia dan kejelasan dalalah. ${ }^{6}$ Dan Ilmu Badi' ini terdiri dari dua bagian, pertama, Muhassanatul Lafdziyyah (keindahan lafadz), kedua, Muhassanatul Ma'nawiyyah (keindahan makna). Muhassanatul Lafdziyyah adalah banwa keindahan dari suatu kalam dilihat dari keindahan lafadz. Dan Muhassanatul Ma'nawiyah adalah yang berhubungan dengan keindahan makna.' Pembahasan mengenai Muhassanatul Ma'nawiyyah adalah At-Tauriyah, At-Thibaq, Al-Muqobalah, Husnu At-Ta'lil, Ta'kid Bima Yusybihu Az-Zam Wa 'Aksahu, dan AtTausyi'.

Al-Muqobalah adalah mendatangkan dua ma'na atau lebih kemudian didatangkan lawan dari ma'na tersebut secara berurutan. ${ }^{9}$ Contohnya firman Allah SWT yang berbunyi:

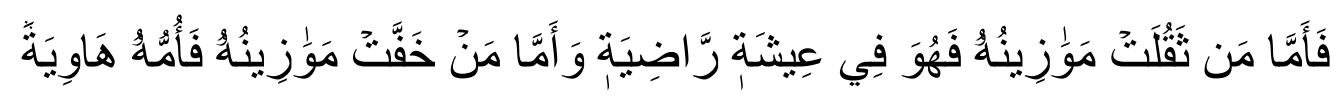

Dalam Ayat di atas Allah SWT telah datang dengan dua ma'na yaitu Tsaqulat Mawaazinuhu dan Fi 'Isyatir Rodhiyah kemudian Allah SWT datang lagi

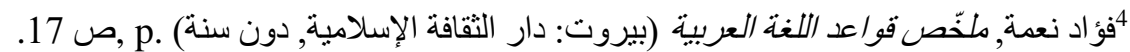

${ }^{5}$ Muhammad Idris Jauhary, Al-Qowaid As-Shorfiyah Mababis 'Anil Kalimaat Al-Arabiyah Fi Hali Ifrodiba (Indonesia: Al-ma'had Al-Amin Al-Islamiyah), p. h. 4.

${ }^{6}$ Muhammad Ghufron Zainal 'Alim, Balaghoh Dalam Ilmu Badi' Untuk Siswa Kelas 6 Di Kulliyatul Mu'allimin Al-Islamiyah Di Pondok Darussala Gontor (Ponorogo: Percetakan Darussalam Gontor, 1991), p. h. 20-21.

${ }^{7}$ Ghufron Zainal 'Alim, p. h. 20-21.

${ }^{8}$ Ghufron Zainal 'Alim, p. h. 20-21.

وعلي الجارم and مصطفي أمين, البلاغة الواضحة البيان والمعاني والبديع للمداس الثانوية (مصر: دار المعارف, 1951) . ص . p. 285.
} 
dengan ma' na yang berlawanan dari ma'na sebelumnya yaitu Khaffat Mawaazinuhu dan Faummuhu Haawiyah secara berurutan. Datang dengan ushlub seperti ini adalah berfungsi untuk keindahan ma'na dan memperjelas ma'na, yaitu mendatangkan kalimat Khaffat Mawaazinuhu dan Faummuhu Haawiyah adalah berfungsi sebagai penjelasan bagi kalimat Tsaqulat Mawaazinuhu dan Fi 'Isyatir Rodhiyah. Dan ushlub ini adalah Ushlub Muqobalah yang datang dengan dua ma'na.

Kemudian firman Allah SWT:

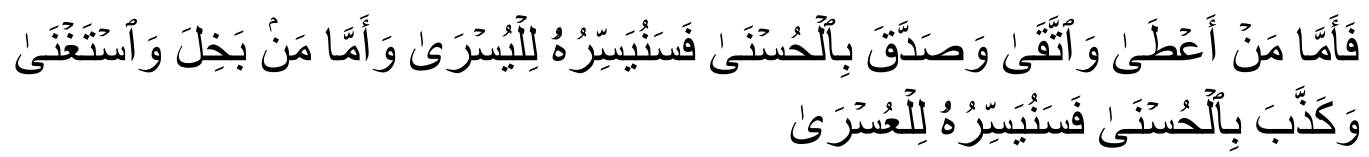

Allah SWT telah datang dengan lebih dari dua ma'na yaitu $A l^{\prime} A t h o^{\prime}$, AtTuqoo, As-Sidq, dan Al-Yusr kemudian datang dengan ma'na-ma'na yang berlawanan dari ma'na-ma'na sebelumnya yaitu Al-buhklu, Al-Istaghna, Al-Kazzab, dan Al-'Usr secara berurutan. Apabila Allah SWT tidak datang dengan ma'nama'na kedua yang berlawanan dengan ma'na-ma' na pertama maka kita tidak akan paham ayat dengan pemahaman yang sebenarnya. Oleh karena itu Al-Qur'an datang dengan ma'na-ma'na kedua yang berlawanan dengan ma'na-ma'na pertama sebagai pemjelasan untuk ma'na-ma'na pertama. Dan datang dengan uhslub seperti ini berfungsi sebagai memperindah ma'na dan memperjelas ma'na. Dan Ushlub ini dinamakan dengan Ushlub Muqobalah yang datang dengan ma'na lebih dari dua.

Ada perbedaan yang cukup jelas antara kita memahami ayat-ayat yang mengandung Ushlub Muqobalah menggunakan analisa nahwu dengan kita memahaminya menggunakan analisa balaghoh. Sebagai contoh firman Allah SWT yang berbunyi:

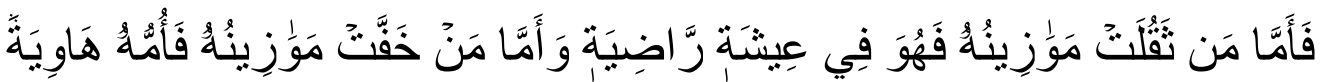

Ayat di atas menurut analisa nahwu adalah merupakan jumlah syarthiyah yang terdiri dari 'adatu syarthi dan jawabu syarthi, yang mana ini dalam pehamamannya, kita hanya diantarkan pada pemahaman jumlah biasa saja. Yaitu tidak jauh berbeda dengan apa yang ada di dalam Al-Qur'an terjemah, "Adapun orang-orang yang berat timbangan kebaikannya, maka dia berada dalam kehidupan yang memuaskan. Adapun orang-orang yang ringan timbangan kebaikannya, maka tempat 
kembalinya adalah neraka Hawiyah". Namun dalam analisa balaghoh ayat ini merupakan Ushlub Al-Muqobalah yang mana berfungsi sebagai penekanan terhadap pemahaman ma'na, dimana ma'na yang kedua memberi penekanan bayaniyah (penjelasan ma'na) terhadap ma'na pertama yaitu ma'na Khaffat Mawaazinuhu dan Faummuhu Haawiyah (Adapun orang-orang yang ringan timbangan kebaikannya, maka tempat kembalinya adalah neraka Hawiyah) sebagai penekanan bayaniyah bagi ma'na Tsaqulat Mawaazinuhu dan Fi 'Isyatir Rodhiyah (Adapun orang-orang yang berat timbangan kebaikannya, maka dia berada dalam kehidupan yang memuaskan). Menurut analisa balaghoh bahwa di dalam Ushlub Al-Muqobalah ada penekanan-penekanan tertentu dalam memahami ayat-ayat AlMuqobalah yang mana ini tidak didapati dalam analisa nahwu, yaitu penekan terhadap ma'na.

Kemudian firman Allah SWT yang berbunyi:

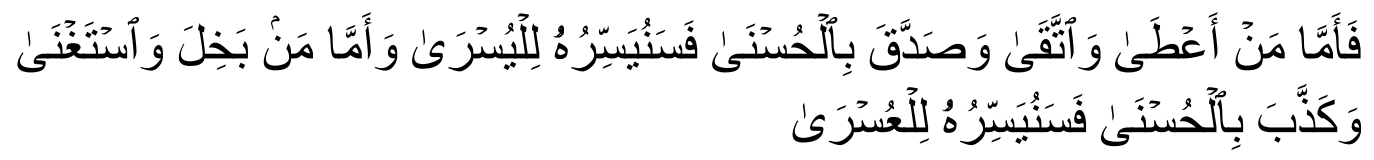

Sama halnya dengan yang di atas, ayat ini jika kita hanya memahaminya dengan analisa nahwu maka kita hanya diantarkan pada pemahaman biasa saja yaitu, "Adapun orang yang memberikan hartanya di jalan Allah dan bertakwa, membenarkan adanya Surga, maka Kami akan menyiapkan baginya jalan yang mudah. Dan adapun orang yang bakhil dan merasa dirinya cukup, serta mendustakan Surga, maka kelak Kami akan menyiapkan baginya jalan yang sukar". Namun jika kita analisa dengan balaghoh maka kita akan dapat menyerap ma'na dengan apa yang diinginkan Allah SWT dengan mendatangkan ayat tersebut, dimana dalam ayat ini Allah SWT menginginkan adanya penekanan terhadap ma'na yang pertama dengan mendatangkan ma'na kedua yang berlawanan dengannya, yaitu ma'na, "Dan adapun orang yang bakhil dan merasa dirinya cukup, serta mendustakan surga, maka kelak Kami akan menyiapkan baginya jalan yang sukar" sebagai penekanan penjelas bagi ma'na "Adapun orang yang memberikan hartanya di jalan Allah dan bertakwa, membenarkan adanya Surga, maka Kami akan menyiapkan baginya jalan yang mudah".

Contoh di atas merupakan sebagian dari Ushlub-ushlub Al-Muqobalah yang ada di dalam Al-Qur'an, masih banyak lagi Ushlub-ushlubAl-Muqobalah yang dapat di temukan di dalam Al-Qur'an khususnya di dalam Juz 'Amma. Dari analisa di 
atas tampaklah perbedaan antara jika kita memahami ayat Al-Muqobalah dengan analisa nahwu dengan kita memahaminya dengan analisa balaghoh. Yaitu jika kita memahami ayat Al-Muqobalah hanya dengan analisa nahwu maka kita hanya diantarkan pada pemahaman yang biasa saja tanpa tahu adanya penekanan ma'na yang ada pada ayat tersebut. Namun jika kita memahaminya dengan analisa balaghoh maka kita akan diantarkan kepada pemahaman adanya penekanan ma'na dalam ayat tersebut dan itulah yang sebenarnya diinginkan Allah SWT dengan mendatangkan ayat-ayat Al-Muqobalah.

Dengan adanya analisa balaghoh maka kita mendapat kejelasan ma'na dalam memahami apa yang diinginkan Allah SWT dengan ayat-ayat-Nya khususnya yang datang dengan Ushlub Al-Muqobalah. Dan kejelasan itu sangat dibutuhkan oleh orang-orang Islam, berdasarkan itulah peneliti ingin melakukan penelitian ilmiah tentang Ushlub Al-Muqobalah di dalam Al-Qur'an, sehingga dengannya orang-orang Islam tidak terlalu ringan atau biasa saja dalam memahami ayat-ayat Al-Qur'an khususnya Ushlub Al-Muqobalah.

\section{METODE}

Penelitian ini adalah penelitian pustaka, dalam penelitian ini penulis menggunakan sumber primer dan sekunder yang berhubungan dengan objek penelitian. Metode dalam mengumpulkan data pada penelitian pustaka ini ialah dengan metode observasi serta membaca buku-buku yang berkaitan dengan judul. Sedangkan metode analisa data dengan analisa deskriptif balaghoh dan analisa kandungan buku-buku (content analisis) dengan menggunakan tabel.

\section{HASIL DAN PEMBAHASAN}

Balaghoh secara bahasa artinya ialah sampai, dikatakan "Fulan telah sampai kepada sesuatu yang Ia inginkan" dengan demikian Ia telah sampai kepada tujuannya. Contoh lainya "pengendara telah sampai di kota" dengan demikian Ia telah sampai kepada tujuannya. ${ }^{10}$ Secara istilah balaghoh adalah mendatangkan makna yang indah secara jelas dengan menggunakan ungkapan yang benar dan fasih. ${ }^{11}$

$$
\begin{aligned}
& \text { 10أحمد الهاشمي, جواهر البلاغة في المعاني والبيان والبديع (إندونيسيا: مكتبة دار إحياء الكتب العربية) . ص . } 31 . \\
& \text { 11الهاشمي .p.p ص } 31 .
\end{aligned}
$$


Balaghoh ialah mendatangkan makna agung dan jelas, dengan ungkapan yang benar dan fasih, memberi bekas yang berkesan di lubuk hati, dan sesuai dengan situasi, kondisi, dan orang-orang yang diajak bicara. ${ }^{12}$ Balaghoh ialah ilmu yang memiliki kaidah, dan seni yang memiliki asal dan perangkat. Dan balaghoh terbagi menjadi tiga bagian yang mendasar, yaitu: ilmu bayan, ilmu ma'ani dan ilmu badi'. ${ }^{13}$

Para Ulama Mutaakhirin telah membagi Balaghoh kepada tiga bagian yaitu Ilmu bayan, Ilmu Ma'any, dan Ilmu Badi'. Dan Ilmu Badi' adalah ilmu yang dapat diketahui darinya gambaran keindahan kalam setelah melihat kesesuaian tingkatan kondisi manusia dan kejelasan dalalah. ${ }^{14}$

\section{Pengertian Badi'}

Badi' secara bahasa mengandung dua makna yang mendasar; yang pertama mengandung arti membuat sesuatu yang baru, yang kedua berarti sesuatu yang menakjubkan. ${ }^{15}$ Ilmu badi' secara istilah ialah ilmu yang dapat diketahui darinya gambaran keindahan kalam setelah melihat kesesuaian tingkatan kondisi manusia dan kejelasan dalalah. ${ }^{16}$ Dan Ilmu Badi ini terdiri dari dua bagian, pertama, Muhassanatul Lafdziyyah (Keindahan Lafadz), kedua, Muhassanatul Ma'nawiyyah (Keindahan Ma'na). Muhassanatul Lafdziyyah adalah banwa keindahan dari suatu kalam dilihat dari keindahan lafadz. Muhassanatul Ma'nawiyah adalah yang berhubungan dengan keindahan ma'na. ${ }^{17}$ Dan pembahasan mengenai Muhassanatul Ma'nawiyyah adalah At-Tauriyah, At-Thibaq, Al-Muqobalah, Husnu AtTa'lil, Ta'kid Bima Yusybihu Az-Zam Wa 'Aksahu, dan At-Tausyi'. ${ }^{18}$

\section{Pengertian Al-Muqobalah}

Al-Muqobalah adalah didatangkannya dua makna atau lebih di bagian awal kalimat, lalu didatangkan makna-makna yang berlawanan dengannya secara tertib pada bagian akhir dari kalimat tersebut. ${ }^{19}$

Al-Muqobalah terbagi menjadi beberapa bagian yaitu; ${ }^{20}$

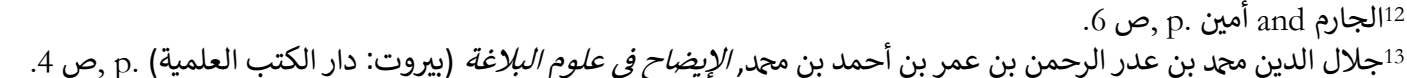

${ }^{14}$ Ghufron Zainal 'Alim, p. h. 20-21.

${ }^{15}$ Ghufron Zainal 'Alim, p. h. 20.

${ }^{17}$ Ghufron Zainal 'Alim, p. h. 21.

${ }^{18}$ Ghufron Zainal 'Alim, p. h. 21.

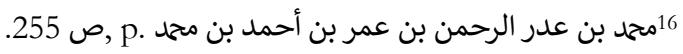

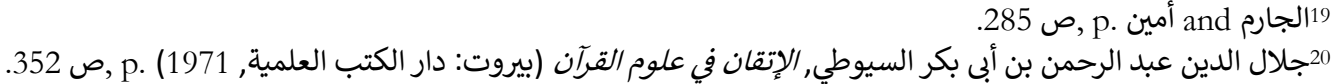


Al-Muqobalah dengan dua makna, contohnya:

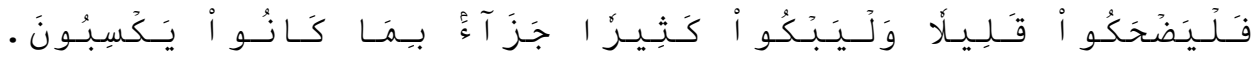

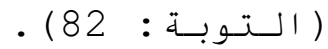

Al-Muqobalah dengan tiga makna, contohnya:

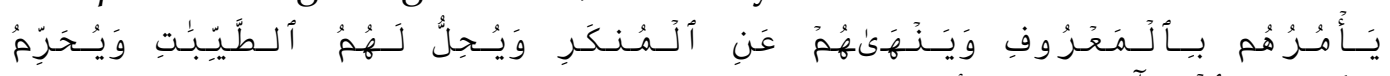

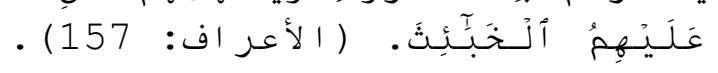

Al-Muqobalah dengan empat makna, contohnya:

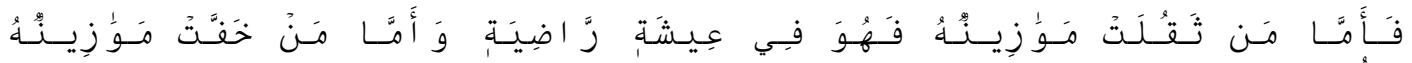

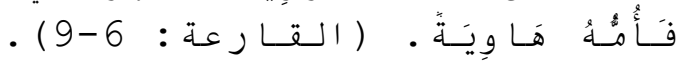

Al-Muqobalah dengan lima makna, contohnya:

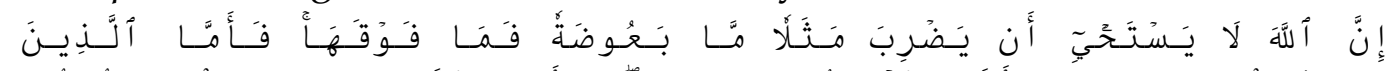

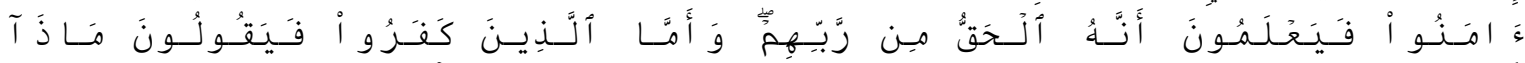

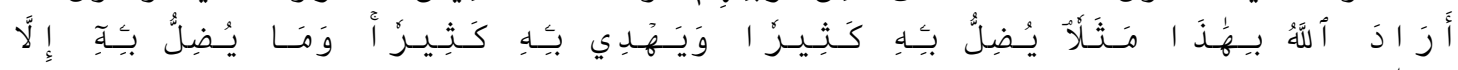

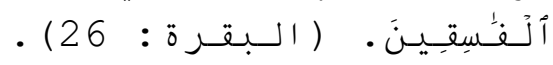

Al-Muqobalah dalam suatu kalimat merupakan salah satu faktor keindahan dan kejelasan maknanya, dengan syarat susunan yang demikian itu dibuat dengan tidak dipaksakan. Adapun bila dipaksakan, justru akan mengikat dan mengekang maknanya, dan kalimatnya tidak lagi indah dan lembut. ${ }^{21}$

Adapun tujuan menurunkan ayat dengan susunan Al-Muqobalah ialah;

1. Untuk memperindah kalam.

2. Untuk memudahkan dalam menghafal.

3. Untuk memberi penekanan terhadap makna.

Adapun Ushlub Al-Muqobalah yang terdapat di dalam Al-Qur'an di Juz 30

\begin{tabular}{|c|c|c|c|c|c|}
\hline No & Surah & Ayat & Makna Pertama & $\begin{array}{l}\text { Makna yang } \\
\text { berlawanan }\end{array}$ & $\begin{array}{l}\text { Jenis Al- } \\
\text { Muqobalah }\end{array}$ \\
\hline 1 & An-Naba' & 10 dan 11 & 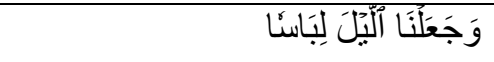 & وَجَعَلْنَا ألنَّهَارَ مَعَانُّا & dua makna \\
\hline 2 & An-Nazi'at & $\begin{array}{ll}27-28 & \text { dan } \\
30-31 & \end{array}$ & 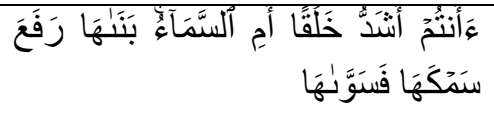 & 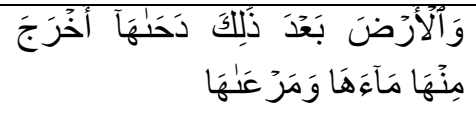 & $\begin{array}{l}\text { Lebih dari dua } \\
\text { makna }\end{array}$ \\
\hline 3 & An-Nazi'at & $\begin{array}{ll}37-39 & \text { dan } \\
40-41 & \end{array}$ & 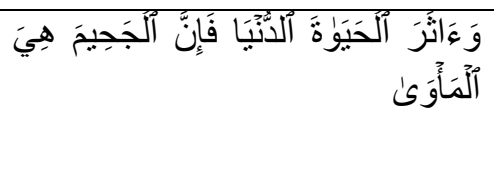 & 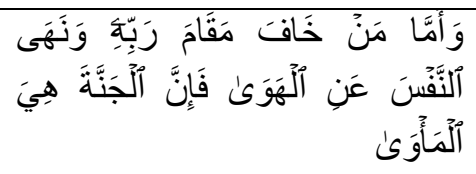 & $\begin{array}{l}\text { Lebih dari dua } \\
\text { makna }\end{array}$ \\
\hline
\end{tabular}
yaitu:

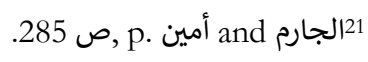




\begin{tabular}{|c|c|c|c|c|c|}
\hline 4 & 'Abasa & 5-6 dan 8-10 & 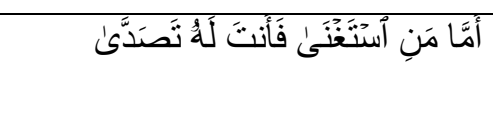 & 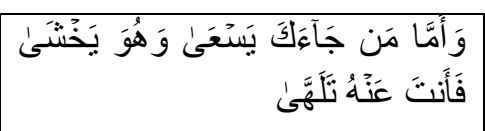 & $\begin{array}{l}\text { Lebih dari dua } \\
\text { makna }\end{array}$ \\
\hline 5 & 'Abasa & 21 dan 22 & 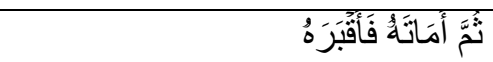 & 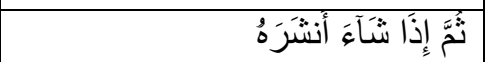 & dua makna \\
\hline 6 & 'Abasa & $\begin{array}{ll}38-39 & \text { dan } \\
40-41 & \end{array}$ & 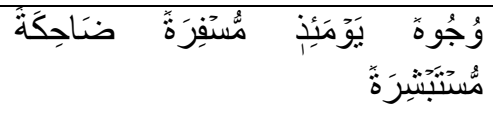 & 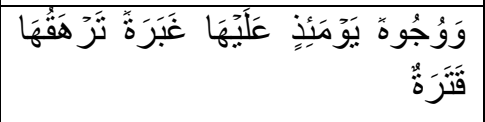 & dua makna \\
\hline 7 & At-Takwir & 17 dan 18 & وَواَلْيْلِلٍ إذذا عَسْعَسَ & 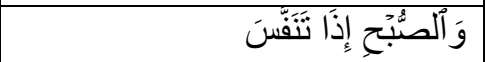 & dua makna \\
\hline 8 & Al-Infitor & 13 dan 14 & إِنَّ ألأَبْرَرَارَ لَفِي نَعِيم & 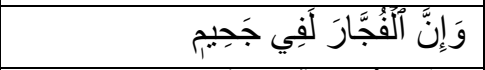 & dua makna \\
\hline 9 & $\begin{array}{l}\text { Al- } \\
\text { Muthoffifin }\end{array}$ & 2 dan 3 & 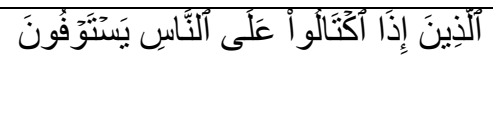 & 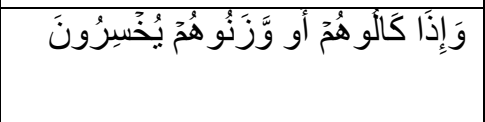 & dua makna \\
\hline 10 & $\begin{array}{l}\text { Al- } \\
\text { Muthoffifin }\end{array}$ & 7 dan 18 & 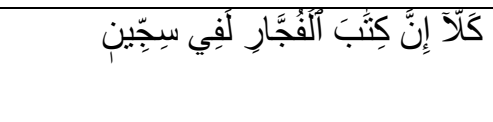 & 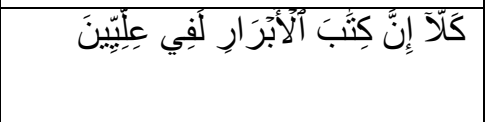 & dua makna \\
\hline 11 & $\begin{array}{l}\text { Al- } \\
\text { Insyiqoq }\end{array}$ & $\begin{array}{l}7-9 \text { dan } 10- \\
13\end{array}$ & 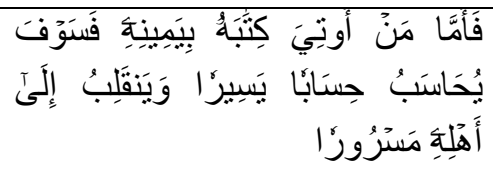 & 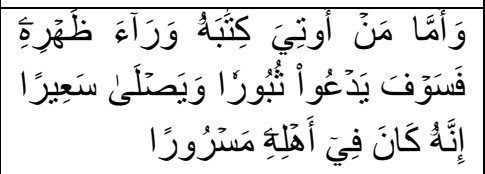 & $\begin{array}{l}\text { Lebih dari dua } \\
\text { makna }\end{array}$ \\
\hline 12 & Al-Buruj & 10 dan 11 & 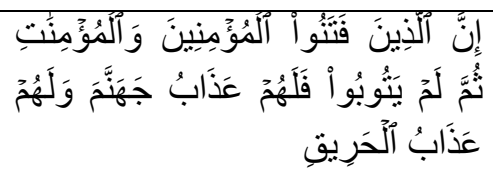 & 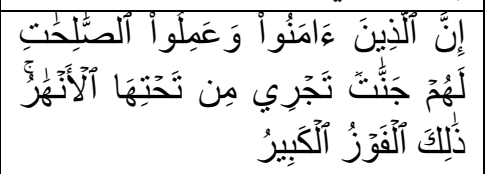 & $\begin{array}{l}\text { Lebih dari dua } \\
\text { makna }\end{array}$ \\
\hline 13 & Al-A'la & 10 dan 11 & 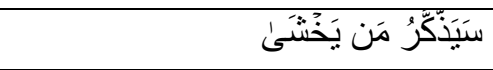 & 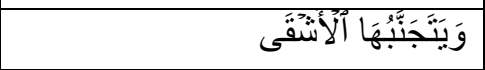 & dua makna \\
\hline 14 & $\begin{array}{l}\text { Al- } \\
\text { Ghosyiah }\end{array}$ & 2-7 dan 8-19 & 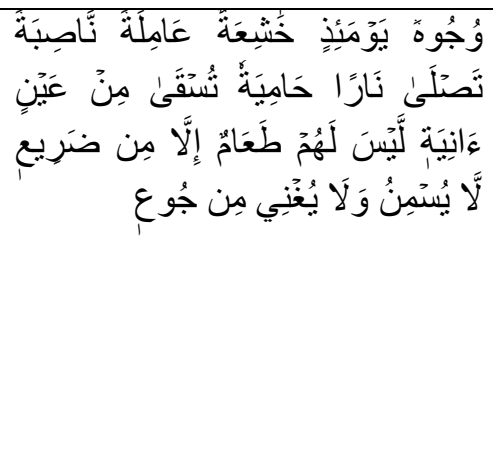 & 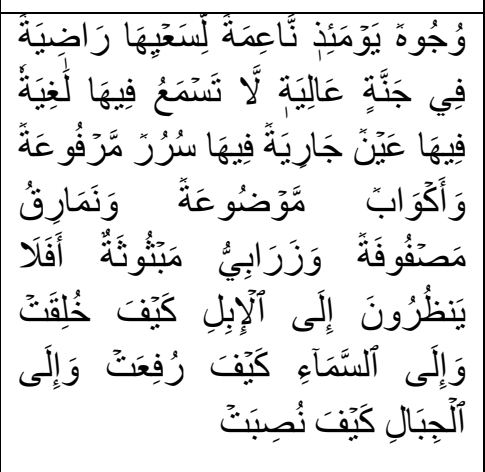 & $\begin{array}{l}\text { Lebih dari dua } \\
\text { makna }\end{array}$ \\
\hline 15 & Al-Fajr & 15 dan 16 & 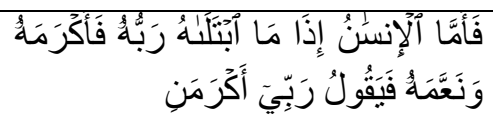 & 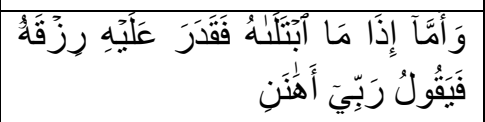 & dua makna \\
\hline 16 & Al-Balad & $\begin{array}{l}17-18 \text { dan } \\
19\end{array}$ & 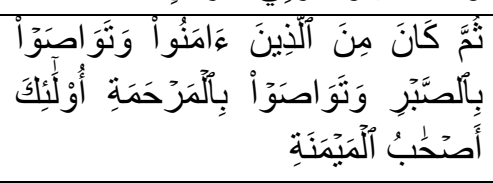 & 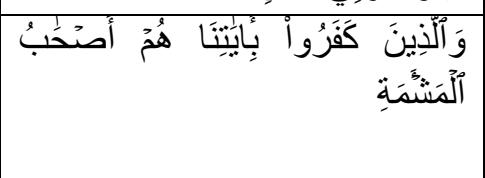 & dua makna \\
\hline 17 & As-Syamsu & 3 dan 4 & 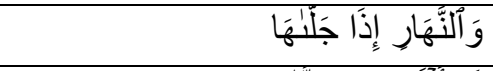 & 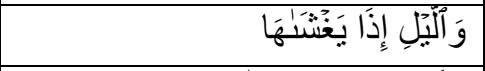 & dua makna \\
\hline 18 & As-Syamsu & 9 dan 10 & 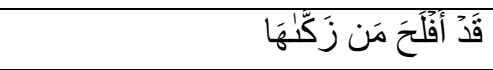 & وَفَقْ خَابَ مَنْ دَسَّلَهَا & dua makna \\
\hline 19 & Al-Lail & 5-7 dan 8-10 & 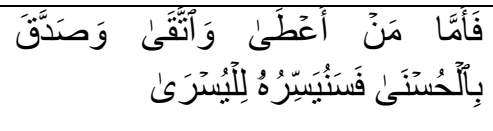 & 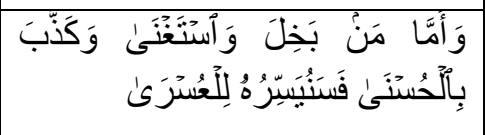 & $\begin{array}{l}\text { Lebih dari dua } \\
\text { makna }\end{array}$ \\
\hline
\end{tabular}




\begin{tabular}{|c|c|c|c|c|c|}
\hline 20 & $\begin{array}{l}\text { Al- } \\
\text { Bayyinah }\end{array}$ & 6 dan 7 & 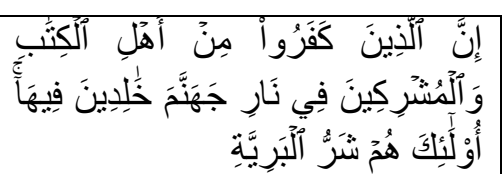 & 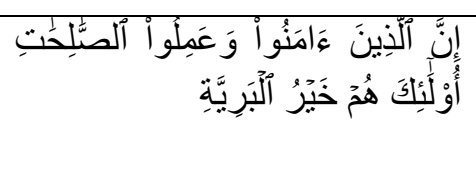 & dua makna \\
\hline 21 & $\begin{array}{l}\text { Az- } \\
\text { Zalzalah }\end{array}$ & 7 dan 8 & 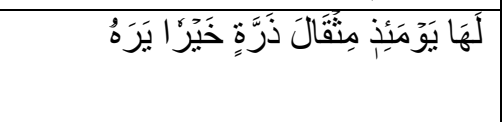 & 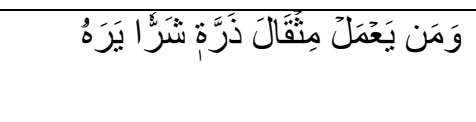 & dua makna \\
\hline 22 & Al-Qori'ah & 6-7 dan 8-9 & 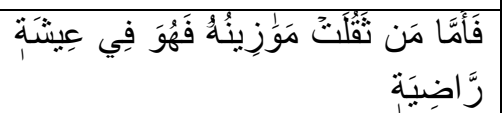 & 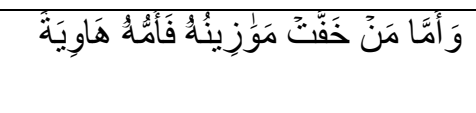 & dua makna \\
\hline 23 & Al-Kafirun & 2 dan 3 & لَا أَعْدُدُ مَا تَعَدُدُونَ & 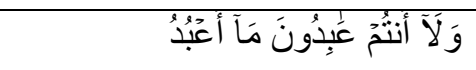 & dua makna \\
\hline 24 & Al-Kafirun & 4 dan 5 & 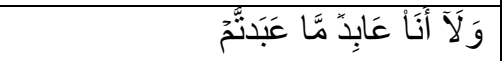 & 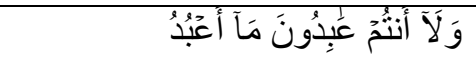 & dua makna \\
\hline
\end{tabular}

\section{KESIMPULAN}

Dari penelitian yang telah dilakukan, maka dapat disimpulkan bahwa:

1. Jumlah ayat yang datang menggunakan susunan kalimat dengan Ushlub AlMuqobalah berjumlah 24 ayat.

2. Jenis Ushlub Al-Muqobalah yang ada di Juz 30 ialah;

a. Ushlub Al-Muqobalah yang berjenis dua makna, yaitu: Nomor 1, 5, 6, 7, 8, 9, 10, $13,15,16,17,18,20,21,22,23$, dan 24 dari daftar yang ada di tabel.

b. Ushlub Al-Muqobalah yang berjenis lebih dari dua makna, yaitu: Nomor 2, 3, 4, 11, 12, 14 dan 19 dari daftar yang ada di tabel.

3. Tujuan mendatangkan ayat Al-Qur'an menggunakan susunan kalimat dengan Ushlub Al-Muqobalah yaitu;

a. Untuk memperindah kalam.

b. Untuk memudahkan dalam menghafal.

c. Untuk memberikan penekanan makna

\section{DAFTAR PUSTAKA}

\section{Al-Qur'an}

Adib Bisri, Kamus Al-Bisri, Indonesia-Arab dan Arab-Indonesia, (Surabaya: Penerbit Pustaka Progressif, 1999)

Aidillah Suja. 2019. " Jurnal PERADA: Jurnal Studi Islam Kawasan Melayu, P-ISSN 2656-7202 E-ISSN 
2655-6626.

http://ejournal.stainkepri.ac.id/index.php/perada/article/view/84/51

Ghufron Zainal 'Alim, Muhammad, Balaghoh Dalam Ilmu Badi' Untuk Siswa Kelas 6

Di Kulliyatul Mu'allimin Al-Islamiyah Di Pondok Darussala Gontor (Ponorogo: Percetakan Darussalam Gontor, 1991)

Idris Jauhary, Muhammad, Al-Qowaid As-Shorfiyah Mabahis 'Anil Kalimaat AlArabiyah Fi Hali Ifrodiha (Indonesia: Al-ma'had Al-Amin Al-Islamiyah)

Mahmud Yunus, Kamus Arab-Indonesia, (Jakarta: PT Mahmud Yunus Wadzuryah, 1989)

Mujio Nurkholis, Bahrun Abu Bakar, dan H. Anwar Abu Bakar, Terjemahan AlBalaaghatul Waadhihah, Sinar Baru Algesindo, Bandung, 2005

Tauhid 2 Untuk Kelas Lima Kulliyatul Mu'allimin Al-Islamiyyah Di Pondok Modern Darussalam (Ponorogo: Percetakan Darussalam Gontor)

$$
\begin{aligned}
& \text { أحمد مصطفي المر اغي، علوم البلاغة البيان والدعاني والبليع، دار الكتب العلمية، بيروت، } 1993 \text { م } \\
& \text { أحمد مصطفي المر اغي، تفسير المراغي المجلد العاشرة (الجز الثلاثثون)، دار الكتب العلمية، بيروت، } 1993 \text { م } \\
& \text { أحمد مطلوب، فنون بلاغية - البيان - البديع، الطبعة الأولى، دار البحوث العلمية، الكويت، } 1395 \text { هـ } 1975 \text { م } \\
& \text { أبى الحسن على بن أحمد الو احدى النيسابورى، أسباب النزول، دار الفكر، بيروت، لبنان، } 1309 \text { هـ - } 1988 \text { م }
\end{aligned}
$$

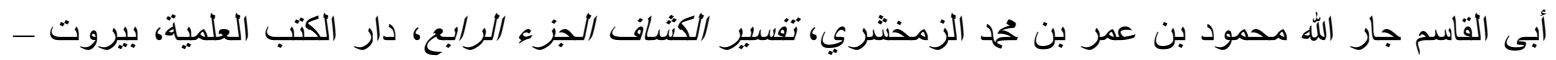

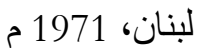

$$
\begin{aligned}
& \text { ابن كثير ، تفسبر /بن كثبر ، مكتبة الثناملة } \\
& \text { الجارم, علي and, مصطفي أمين, البلاغة الواضحة البيان والمعاني والبديع للددارس الثانوية (مصر : دار المعارف, } \\
& \text { القطان, مناع, مباحث في علوم القرآن (سورابايا: طبع على نفقة مكتبة ومطبعة الهداية) } \\
& \text { الهانمي, أحمد, جواهر البلاغة في الدعاني والبيان والبديع (إندونيسيا: مكتبة دار إحباء الكتب العربية) } \\
& \text { عبد الرحمن بن أبى بكر السيوطي, جلال الدين, الإتقان في علوم القرآن (بيروت: دار الكتب العلمية, 1971) } \\
& \text { محمد بن عدر الرحمن بن عمر بن أحمد بن محح, جلال الدين, الإيضاح في علوم البلاغة (بيروت: دار الكتب العلمية) } \\
& \text { محمد علي الصابوني، التبيان في علوم القرآن، ديناميكا بركة أوتما، جاكرتا } \\
& \text { مصطفي الغلايين، جامع الدروس العربية، دار الفكر، بيروت_لبنان، } 2007 \text { م }
\end{aligned}
$$




$$
\begin{aligned}
& \text { المكتبة الشاملة } \\
& \text { المنجد في اللغة والأعلام، طبعة جديدة منقحة، دار المشرق-بيروت، } 2002 \text { م } \\
& \text { نعمة, فؤاد, ملّّص قواعد اللغة العربية (بيروت: دار الثقافة الإسلامية, دون سنة) }
\end{aligned}
$$

